\title{
Serological variation in oral Streptococcus milleri
}

\author{
T. YAKUSHIJI, R.KONAGAWA, MOTOKO ODA and M. INOUE
}

Department of Preventive Dentistry, Kagoshima University Dental School, 1208-1 Usuki-cho, Kagoshima 890. Japan

\begin{abstract}
Summary. Serological variation in 71 oral isolates and three reference strains of Streptococcus milleri was examined. Antisera were raised by immunising rabbits with cells of 10 selected strains, followed by absorption of non-specific antibodies. Double diffusion of the typing sera and the Rantz and Randall extracts of the strains in agar gel demonstrated that 70 strains were divided into 10 serotypes $(a-j)$ on the basis of cell-surface carbohydrate antigens. Only four strains were untypable. The typing scheme proposed depends on type antigens other than the Lancefield group antigens $\mathrm{A}, \mathrm{C}, \mathrm{F}, \mathrm{G}$ and others, although strains belonging to the serotypes $a, c$ and $f$ strictly corresponded to those of the groups $\mathrm{A}, \mathrm{C}$ and $\mathrm{F}$ respectively. Close correlation between the present serotyping scheme and the previously proposed biotyping scheme for $S$. milleri was demonstrated. Distribution of these strains in dental plaque obtained from young adults was also investigated.
\end{abstract}

\section{Introduction}

The role of Streptococcus milleri in clinical infections has been appreciated increasingly (Parker and Ball, 1976; Shlaes et al., 1981; van der Auwera, 1985; Admon et al., 1987; Kambal, 1987). $S$. milleri is a common organism in certain areas of the body and is closely associated with infection in various organs as well as the mouth (Bowden et al., 1975; Edwardson and Mejàre, 1978; Poole and Wilson, 1979).

Several investigators have reported similarities between biochemical and genetic aspects of the organisms (Labbe et al., 1985; Coykendall et al., 1987). However, S. milleri strains vary in some of their characteristics, including haemolysis (Colman and Williams, 1972; Ball and Parker, 1979), cellular fatty-acid fingerprint (Drucker and Lee, 1981), cellwall sugar composition (Aluyi and Drucker, 1983), and DNA base pair ratios $(\mathrm{mol} \% \mathrm{G}+\mathrm{C}$, Drucker and Lee, 1983). Furthermore, like other viridans streptococci, $S$. milleri strains are serologically heterogeneous; they often carry Lancefield group antigens $\mathrm{A}, \mathrm{C}, \mathrm{F}$ and $\mathrm{G}$, or Ottens type antigens $\mathrm{I}$, II, III, IV and V, or both (Colman and Williams, 1972; Lütticken et al., 1978); however, a significant number of $S$. milleri strains are ungroupable and untypable.

Serological classification of these clinically im-

Received 5 Jan. 1988; revised version accepted 25 Mar. 1988. portant streptococci would be of great value not only for taxonomic studies but also for ecological and epidemiological studies. The provision of a simple, rapid and reliable method to determine sources and transmission of systemic infections would be valuable. In an earlier report we isolated 71 strains of $S$. milleri from the dental plaque of 15 young adults and demonstrated a variety of physiological profiles in these strains (Yakushiji et al., in press). The aim of the present study was to determine serological variation in oral strains of $S$. milleri.

\section{Materials and methods}

\section{S. milleri strains}

A total of 71 clinical isolates and three reference strains of $S$. milleri was used. Physiological characteristics of the strains have been described previously (Yakushiji et al., in press). They were grown in Brain Heart Infusion Broth (BHI) (Difco) anaerobically at $37^{\circ} \mathrm{C}$ for $18 \mathrm{~h}$.

\section{Protocol for immunisation}

Ten strains were selected as immunogens to prepare typing antisera (table I). Cells of the strains were collected by centrifugation at $6000 \mathrm{~g}$ for $20 \mathrm{~min}$ at $4^{\circ} \mathrm{C}$ from the BHI cultures, washed three times in distilled water, and lyophilised. They were then resuspended to a concentration of $0.5 \mathrm{mg}$ (dry weight)/ml in saline containing merthiolate $0.025 \%$.

Female rabbits weighing around $3 \mathrm{~kg}$ were given 
intravenous injections of the whole-cell suspensions on alternate days ( 3 days a week) for 3 weeks; $0.5 \mathrm{ml}, 1.0 \mathrm{ml}$ and $2.0 \mathrm{ml}$ were injected on the first, second and third weeks, respectively. Blood was collected about 10 days after the last injection.

\section{Preparation of typing antisera}

To prepare type-specific antisera, crude antisera were absorbed with the whole cells of cross-reacting strains. One $\mathrm{ml}$ of antiserum was added to $50 \mathrm{mg}$ (dry weight) of cells in $1 \mathrm{ml}$ of distilled water and incubated at $37^{\circ} \mathrm{C}$ for $1 \mathrm{~h}$, then at $4^{\circ} \mathrm{C}$ overnight with occasional shaking. Finally the cells were removed by centrifugation at $3000 \mathrm{rpm}$ for $10 \mathrm{~min}$ at $4^{\circ} \mathrm{C}$. The absorption procedures were repeated if necessary under the same condition until all non-specific antibodies were removed. When the antibody titre was markedly lowered by absorption, antiserum was concentrated by use of Collodion Bags (Sartorius GmbH, Göttingen) or an Amicon membrane (PM10, Amicon Corporation, Massachusetts).

\section{Preparation of antigens}

Cell-surface carbohydrate antigens were extracted from the lyophilised cells according to the method of Rantz and Randall (1955) (RR extract). Cells were resuspended in saline at a concentration of $20 \mathrm{mg} / \mathrm{ml}$ and heated at $120^{\circ} \mathrm{C}$ for $20 \mathrm{~min}$; the supernate was then separated by centrifugation.

\section{Immunodiffusion}

Double diffusion in agar gel was performed by the routine method in Noble Agar (Difco) $1 \%$ gel in $0.01 \mathrm{M}$ sodium phosphate buffer containing $0.15 \mathrm{M} \mathrm{NaCl}$ and $\mathrm{NaN}_{3} 0 \cdot 1 \%$; the $\mathrm{pH}$ was $7 \cdot 2$. Appropriate amounts of the $\mathrm{RR}$ extracts and immune sera (c. $25 \mu \mathrm{l})$ were placed in wells and incubated overnight at room temperature.

\section{Reagents}

All the chemicals used were purchased from commercial sources. Lancefield group antigens $A-G$ and antisera to these (the Bacto-Streptococcus Antigen/Antisera set) were from Difco.

Biotypes, haemolysis and colonial forms of the strains used in this study have been reported previously (Yakushiji et al., 1988).

\section{Results}

\section{Serotyping of oral isolates of S. milleri}

Immune sera were obtained by immunising rabbits with whole cells of three reference and seven oral strains (table I). Double diffusion in gel demonstrated that six of the antisera reacted with
Table I. $S$. milleri strains used as immunising agents or absorbents

Antisera

$\begin{array}{ccc}\begin{array}{c}\text { raised with cells of } \\ \text { strain (biotype) }\end{array} & \begin{array}{c}\text { absorbed with cells of } \\ \text { strain (biotype/serotype) }\end{array} & \begin{array}{c}\text { Serotype } \\ \text { designation }\end{array}\end{array}$

\begin{tabular}{|c|c|c|c|}
\hline FW73 & (Ia) & - & $a$ \\
\hline $10708^{1}$ & (Ia) & $\mathrm{K} 214-2 \mathrm{~K}\left(\mathrm{Ia} /-^{*}\right)$ & $b$ \\
\hline K51 $\mathrm{Y}^{2}$ & (Ia) & $\mathrm{K} 217 \mathrm{~K} \quad(\mathrm{Ia} / d)$ & $c$ \\
\hline $\mathrm{K} 215-1 \mathrm{~K}$ & (Ia) & - & $d$ \\
\hline K226K & (Ia) & - & $e$ \\
\hline 9895 & (Ia) & - & $f$ \\
\hline $\mathrm{K} 1 \mathrm{~K}^{3}$ & (IIc) & $\mathrm{K} 201 \mathrm{~K}$ & $g$ \\
\hline Y.18K & (IIc) & - & $h$ \\
\hline K $39 K^{4}$ & (Ia) & $\mathrm{K} 16-1 \mathrm{~K} \quad(\mathrm{IIc} / h)$ & $i$ \\
\hline K $201 \mathrm{~K}$ & (IIb) & - & $j$ \\
\hline
\end{tabular}

FW73, S. milleri FW73, 10708; S. milleri NCTC 10708; 9895, $S$. MG ATCC 9895 . -, none or *untypable. The four crude antisera (1-4) also cross-reacted with the following strains. 1 : $\mathrm{K} 218 \mathrm{~K}(\mathrm{Ia} /-) ; 2$ : K215-1K (Ia/d), K216K (Ia/d); 3: K213K (IIc/ - ) ; 4: K235K (Ia/h), K236K (Ia/h), K16-2K (IIb/h), K18K (IIc/h), K232-2K (IIc/h), K233aK (IIc/h), K233K (IId/h).

the RR antigens of different $S$. milleri strains. In contrast, the remaining four antisera, anti-10708, anti-K $51 \mathrm{Y}$, anti-K $1 \mathrm{~K}$ and anti-K $39 \mathrm{~K}$, cross-reacted with RR extracts of several strains (see below). Absorption of these sera with whole cells (table I) removed non-specific antibodies (fig. 1). The 10 specific antisera thus obtained were used as standardised typing sera (fig. 2). Serotypes are listed in table I.

RR antigen extracts of 70 strains each reacted with only one of the 10 specific typing antisera. Precipitin lines formed with RR extracts of the strains clustered in one type completely fused with the line formed between the typing antiserum and its homologous antigen extract (fig. 3).

Thus, the majority of the $S$. milleri strains examined here were divisable into 10 serotypes, tentatively designated $a-j$ (table I). Only four strains were untypable. Distribution of the $S$. milleri strains among these serotypes are summarised in table II. Serotypes $f$ and $i$ constituted major clusters, serotypes $c, g$ and $h$ were intermediate and the other serotypes were less prominent.

Strains of serotypes $d$ and $h$ produced crossreacting bands with the crude antisera against cells of strains K51Y (serotype $c$ ) and K39K (i) respectively (table I). The serotype $j$ strain produced a precipitin line cross-reacting with the crude antiK $1 \mathrm{~K}(g)$ serum. Also, one untypable strain crossreacted with the anti-K1K $(g)$ serum and the other two untypable strains (both of which contained the 


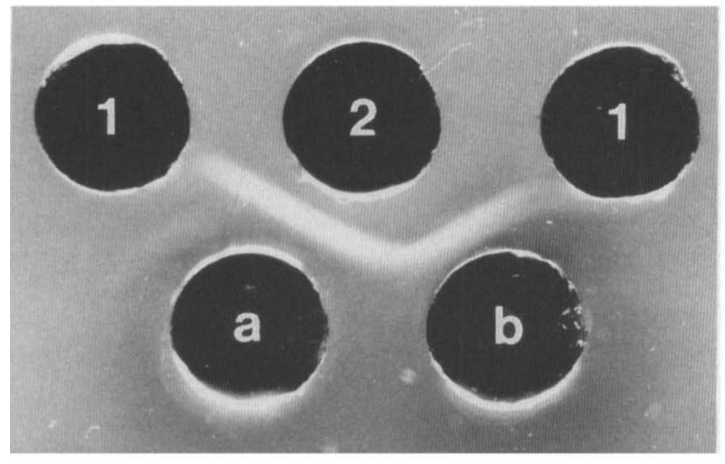

Fig. 1. Preparation of type-specific antiserum. Anti-K51Y serum (well a) yielded cross-reacting precipitin lines with RR extracts of strains $\mathrm{K} 217 \mathrm{~K}$ (well 1) and $\mathrm{K} 51 \mathrm{Y}$ ( (well 2). After absorption with the strain $\mathrm{K} 217 \mathrm{~K}$ cells, the resultant antiserum (anti-c serum; well b) did not react with the antigen extract of the absorbent strain (well 1). Precipitin lines of the anti-K51Y and anti- $c$ sera with the K51Y antigen fused.

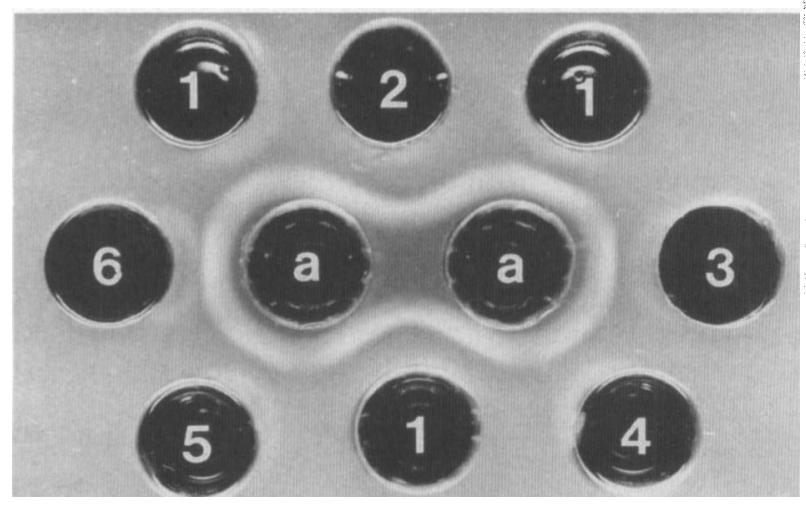

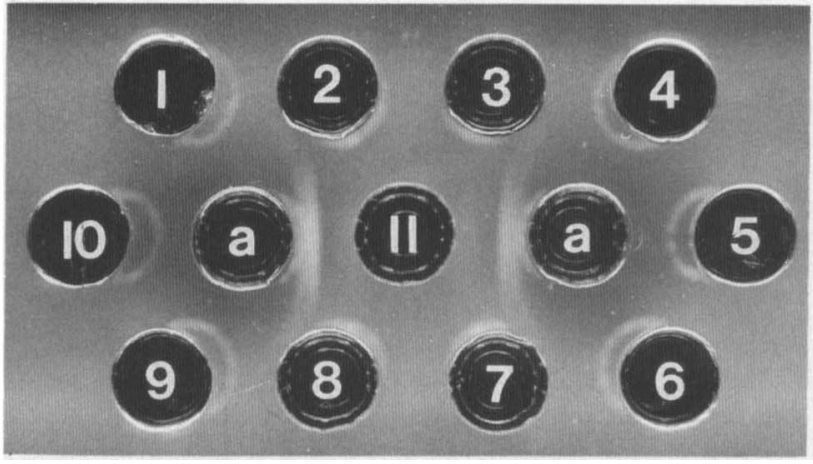

Fig. 2. Specificity of a typing serum. Anti-c serum (wells a) reacted only with the homologous RR antigen (well 11) among the antigen extracts of the 10 vaccine strains and one untypable strain (wells 1-11). Well 1, FW73 (a); 2, $10708(b) ; 3$, K215-1K (d); 4, K226K (e); 5, $9895(f) ; 6, \mathrm{~K} 1 \mathrm{~K}(g) ; 7, \mathrm{~K} 18 \mathrm{~K}(h) ; 8, \mathrm{~K} 39 \mathrm{~K}$ (i); 9, K201K (j); 10, K214-2K (untypable); 11, K51Y (c).

Fig. 3. Clustering of $S$. milleri strains by a typing serum. Anti- $c$ serum (wells a) reacted with the RR extracts of all the strains clustered in serotype $c$ (wells 1-6), yielding precipitin lines fusing with that produced between the typing serum and its homologous RR extract (well 1). Well 1, K51Y; 2, K59YS; 3, K59YL; 4, $\mathrm{K} 103 \mathrm{~K} ; 5, \mathrm{~K} 104 \mathrm{~K} ; 6, \mathrm{~K} 106 \mathrm{~K}$.

Table II. Distribution of oral S. milleri strains among serotypes and Lancefield groups

\begin{tabular}{|c|c|c|c|c|c|c|c|c|}
\hline \multirow[b]{2}{*}{ Serotype } & \multicolumn{3}{|c|}{$\begin{array}{l}\text { Number of strains belonging } \\
\text { to serotype }\end{array}$} & \multicolumn{5}{|c|}{$\begin{array}{l}\text { Number of strains with } \\
\text { Lancefield group antigen }\end{array}$} \\
\hline & $\begin{array}{l}\text { reference } \\
\text { (3) }\end{array}$ & $\begin{array}{l}\text { clinical } \\
(71)\end{array}$ & $\begin{array}{c}\text { total } \\
(74)\end{array}$ & $\begin{array}{c}\text { A } \\
(1)\end{array}$ & $\begin{array}{c}C \\
(6)\end{array}$ & $\begin{array}{c}F \\
(24)\end{array}$ & $\begin{array}{c}G \\
(2)\end{array}$ & $\begin{array}{l}\text { UG } \\
(41)\end{array}$ \\
\hline$a$ & 1 & 0 & 1 & 1 & 0 & 0 & 0 & 0 \\
\hline$b$ & 1 & 3 & 4 & 0 & 0 & 0 & 0 & 4 \\
\hline$c$ & 0 & 6 & 6 & 0 & 6 & 0 & 0 & 0 \\
\hline$d$ & 0 & 3 & 3 & 0 & 0 & 0 & 0 & 3 \\
\hline$e$ & 0 & 2 & 2 & 0 & 0 & 0 & 0 & 2 \\
\hline$f$ & 1 & 23 & 24 & 0 & 0 & 24 & 0 & 0 \\
\hline$g$ & 0 & 6 & 6 & 0 & 0 & 0 & 0 & 6 \\
\hline$h$ & 0 & 8 & 8 & 0 & 0 & 0 & 0 & 8 \\
\hline$i$ & 0 & 15 & 15 & 0 & 0 & 0 & 0 & 15 \\
\hline$j$ & 0 & 1 & 1 & 0 & 0 & 0 & 0 & 1 \\
\hline UT & 0 & 4 & 4 & 0 & 0 & 0 & 2 & 2 \\
\hline
\end{tabular}

$\mathrm{UG}=$ ungroupable $; \mathrm{UT}=$ untypable. 
Lancefield group $G$ antigen) with the anti-10708 (b) serum.

\section{Relation of serotypes and Lancefield groups}

Reactivity of antigen extracts with Lancefield grouping sera indicated that the serotype $a$ strain (1 strain), the type $c$ strains (6 strains), the type $f$ strains (24 strains), and the untypable strains (2 strains) carried the Lancefield group antigens A, C, F, and G respectively (table II). As shown in fig. 4, the commercial anti-group $\mathrm{C}$ serum yielded a fusing precipitin line with the $\mathbf{R}$ antigen extract of strain K51Y (serotype $c$ ) and the commercial group C antigen preparation. However, the anti-c (K51Y) serum did not react with the group $C$ antigen although the K51Y $(c)$ antigen cross-reacted with the type $c$ serum and the anti-C serum. Similar results were demonstrated between serotype $a$ and Lancefield group A and between serotype $f$ and group F.

\section{Relations between serotypes and biological characteristics}

Table III shows that all the 16 strains classified as serotypes $a-e$ belonged to the biotype Ia, and the 24 serotype $f$ strains to the biotypes Ia or Ib. Most strains of serotypes $g$ - $j$ were members of the biotype II, mostly subtypes IIc and IId.

Most (20 out of 24 ) of the serotype $f$, group $\mathrm{F}$ strains and the untypable ( 3 of 4 ) or group G ( 2 of 2) strains produced rough forms on Carlsson's MC agar plates or changed the appearance of their colonies on blood, MS and MC media (table IV). Among others, only one or two of each of the

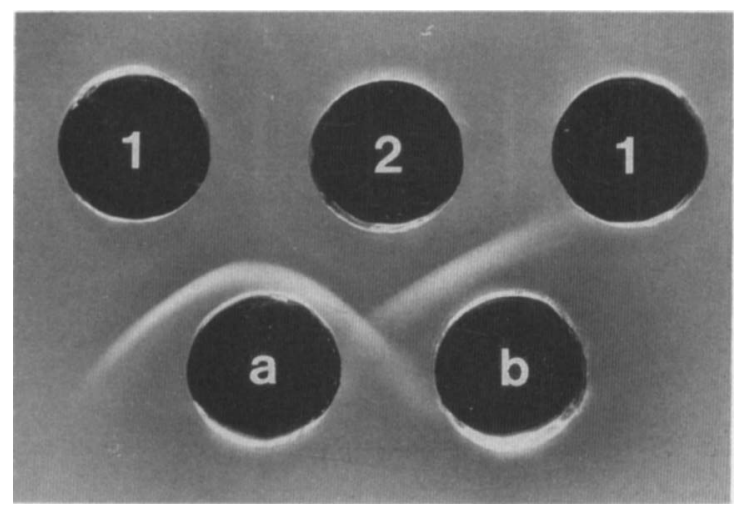

Fig. 4. Independence of a typing serum from Lancefield group antigens. RR extracts of the type $c$ vaccine strain K51Y (well 2) cross-reacted with anti- $c$ serum (well $b$ ) and anti-group $C$ serum (well a). Anti- $c$ serum did not react with group $\mathrm{C}$ antigen (well 1). Precipitin lines of group $C$ and type $c$ antigens with group $C$ serum fused.
Table III. Relation between serotypes and biotypes

\begin{tabular}{|c|c|c|c|c|c|c|c|}
\hline \multirow[b]{2}{*}{ Serotype } & \multirow[b]{2}{*}{$\begin{array}{l}\text { Number } \\
\text { of strains }\end{array}$} & \multicolumn{6}{|c|}{ Number of strains of biotype } \\
\hline & & $\begin{array}{c}\text { Ia } \\
(32)\end{array}$ & $\begin{array}{c}\text { Ib } \\
(15)\end{array}$ & $\begin{array}{l}\text { IIa } \\
\text { (4) }\end{array}$ & $\begin{array}{l}\text { IIb } \\
\text { (4) }\end{array}$ & $\begin{array}{l}\text { IIc } \\
(10)\end{array}$ & $\begin{array}{l}\text { IId } \\
\text { (9) }\end{array}$ \\
\hline$a$ & 1 & 1 & 0 & 0 & 0 & 0 & 0 \\
\hline$b$ & 4 & 4 & 0 & 0 & 0 & 0 & 0 \\
\hline$c$ & 6 & 6 & 0 & 0 & 0 & 0 & 0 \\
\hline$d$ & 3 & 3 & 0 & 0 & 0 & 0 & 0 \\
\hline$e$ & 2 & 2 & 0 & 0 & 0 & 0 & 0 \\
\hline$f$ & 24 & 10 & 14 & 0 & 0 & 0 & 0 \\
\hline$g$ & 6 & 0 & 0 & 1 & 1 & 3 & 1 \\
\hline$\stackrel{\circ}{h}$ & 8 & 2 & 0 & 0 & 1 & 4 & 1 \\
\hline$i$ & 15 & 1 & 1 & 3 & 1 & 2 & 7 \\
\hline$j$ & 1 & 0 & 0 & 0 & 1 & 0 & 0 \\
\hline UT & 4 & 3 & 0 & 0 & 0 & 1 & 0 \\
\hline
\end{tabular}

$\mathrm{UT}=$ untypable.

ungroupable $b, g, h$ and $i$ strains produced rough colonies or a change in colonial appearance.

Only a few strains of the serotypes $a$ and $f$, the ungroupable serotypes $b$ and $d$, and the untypable group $\mathrm{G}$ were $\alpha$-haemolytic.

\section{Distribution of serotypes in plaque samples}

Table $\mathrm{V}$ summarises the frequencies of various serotypes in plaque samples. The serotype $f$ strains which were the most widely distributed, were isolated from 6 of the 15 plaque samples. Serotype $i$ and serotypes $g$ and $h, b$ and $c$, and $d, e$ and $j$ were isolated from four, three, two, and one plaque samples, respectively. No serotype $a$ strain was detected in any of the samples examined.

Serological variations amongst strains from any one plaque sample were not so marked. One or two serotypes were usually found in each sample. Three serotypes were detected in only two samples.

\section{Discussion}

Considerable serological variations amongst $S$. milleri strains have been known: the Lancefield group antigens and the Ottens type antigens (Ottens and Winkler, 1962) are distributed among the streptococcal cluster (Colman and Williams, 1972; Lütticken et al., 1978). The present findings indicate that there are far more serological varieties of $S$. milleri than are identified by grouping and typing systems reported hitherto. Oral strains of $S$. milleri were divided into 10 or more types based on variations in their cell-surface carbohydrate antigens. 
Table IV. Relation of serotypes/serogroups and colonial morphology

\begin{tabular}{|c|c|c|c|c|}
\hline \multirow[b]{2}{*}{$\begin{array}{l}\text { Lancefield } \\
\text { group }\end{array}$} & \multirow[b]{2}{*}{ Serotype } & \multirow[b]{2}{*}{$\begin{array}{l}\text { Total } \\
\text { number of } \\
\text { strains } \\
(47)\end{array}$} & \multicolumn{2}{|c|}{ Number of strains producing } \\
\hline & & & $\begin{array}{c}\text { rough colonies } \\
\text { on MC agar } \\
\text { (25) }\end{array}$ & $\begin{array}{c}\text { colonial form } \\
\text { change }(S \notin R) \\
(26)\end{array}$ \\
\hline F & $f$ & 24 & 19 & 20 \\
\hline G & UT & 2 & 2 & 2 \\
\hline UG & $b$ & 4 & 1 & 0 \\
\hline UG & $g$ & 6 & 0 & 1 \\
\hline UG & $h$ & 8 & 1 & 2 \\
\hline UG & $i$ & 1 & 1 & 0 \\
\hline UG & UT & 2 & 1 & 1 \\
\hline
\end{tabular}

$\mathrm{UG}=$ ungroupable $\mathbf{U T}=$ untypable.

The serological variations appeared to correspond well to the biological variations of $S$. milleri demonstrated previously (Yakushiji et al., in press); strains belonging to serotypes $a-f$ were confined to biotype I whereas most strains of other serotypes were of biotype II (table III).

A significant number of $S$. milleri strains have been shown to carry Lancefield group antigens $A$, C, F or G (Colman and Williams, 1972; Ball and Parker, 1979; Yakushiji et al., in press). The observation that the serotypes $a, c$ and $f$ strains and the group $\mathrm{A}, \mathrm{C}$, and $\mathrm{F}$ strains strictly correspond to each other suggests the possibility that the specific antibodies contained in the anti- $a,-c$ and $-f$ antisera are the anti-A, $-\mathrm{C}$ and $-\mathrm{F}$ antibodies, respectively. Indeed, RR extracts of the vaccine strains FW73 $(a), \mathrm{K} 51$ Y (c) or ATCC9895 (f) cross-reacted with the corresponding typing serum and group-specific reference serum, but the typing serum did not react with the paired reference group antigen (fig. 4). These observations indicate that the specific antibodies in these typing antisera were not derived from the group antigens. Thus, all the 10 typing antisera, including the above three, are type

Table V. Distribution of oral $S$. milleri serotypes in 15 plaque samples

\begin{tabular}{|c|c|c|c|c|c|c|c|c|c|c|c|c|c|}
\hline \multirow[b]{2}{*}{$\begin{array}{l}\text { Plaque } \\
\text { sample }\end{array}$} & \multicolumn{12}{|c|}{ Number of strains in serotype } & \multirow{2}{*}{$\begin{array}{c}\text { Number of } \\
\text { serotypes } \\
\text { /sample }\end{array}$} \\
\hline & $\begin{array}{c}a \\
(0)\end{array}$ & $\begin{array}{c}b \\
(3)\end{array}$ & $\begin{array}{c}c \\
(6)\end{array}$ & $\begin{array}{c}d \\
(3)\end{array}$ & $\begin{array}{c}e \\
(2)\end{array}$ & $\underset{(23)}{f}$ & $\begin{array}{c}g \\
(6)\end{array}$ & $\begin{array}{c}h \\
(8)\end{array}$ & $\begin{array}{c}i \\
(15)\end{array}$ & $\underset{(1)}{j}$ & $\begin{array}{l}\text { UT } \\
\text { (4) }\end{array}$ & $\begin{array}{c}\text { Total } \\
(71)\end{array}$ & \\
\hline IK & 0 & 1 & 0 & $\mathbf{0}$ & 0 & $\mathbf{0}$ & 0 & $\mathbf{0}$ & $\mathbf{0}$ & 0 & 0 & 1 & 1 \\
\hline KK & 0 & 0 & 3 & 0 & 0 & 1 & 0 & $\mathbf{0}$ & 0 & 0 & 0 & 4 & 2 \\
\hline $\mathbf{M M}$ & 0 & 0 & 0 & 0 & 0 & 0 & $\mathbf{0}$ & $\mathbf{0}$ & 0 & 0 & 1 & 1 & 1 \\
\hline MK & 0 & 0 & 0 & 0 & 0 & 3 & 0 & 0 & 0 & 0 & 0 & 3 & 1 \\
\hline HK & 0 & 0 & 0 & 0 & 0 & 1 & 0 & 3 & 4 & 0 & 0 & 8 & 3 \\
\hline YI & 0 & 0 & 0 & 0 & 0 & 4 & 0 & 2 & 0 & 0 & 0 & 6 & 2 \\
\hline IH & 0 & 2 & 3 & 0 & 0 & 0 & 0 & 0 & 0 & 0 & 0 & 5 & 2 \\
\hline NT & 0 & 0 & 0 & 3 & 0 & 0 & 1 & 0 & 0 & 0 & 3 & 7 & 3 \\
\hline MT & 0 & 0 & 0 & 0 & 2 & 0 & 0 & 3 & 0 & 0 & 0 & 5 & 2 \\
\hline $\mathrm{TA}$ & 0 & 0 & 0 & 0 & 0 & 1 & 0 & 0 & 7 & 0 & 0 & 8 & 2 \\
\hline YK & 0 & 0 & 0 & 0 & 0 & 13 & 0 & 0 & 0 & 0 & 0 & 13 & 1 \\
\hline YA & 0 & 0 & 0 & 0 & 0 & 0 & 2 & 0 & 0 & 0 & 0 & 2 & 1 \\
\hline YY & 0 & 0 & 0 & 0 & 0 & 0 & 3 & 0 & 0 & 0 & 0 & 3 & 1 \\
\hline AY & 0 & 0 & 0 & 0 & 0 & 0 & 0 & 0 & 3 & 0 & 0 & 3 & 1 \\
\hline $\mathrm{TF}$ & 0 & 0 & 0 & 0 & 0 & 0 & 0 & 0 & 1 & 1 & 0 & 2 & 2 \\
\hline \multicolumn{14}{|c|}{ Number of positive samples } \\
\hline All & 0 & 2 & 2 & 1 & 1 & 6 & 3 & 3 & 4 & 1 & 2 & & \\
\hline
\end{tabular}

$\mathrm{UT}=$ untypable. 
specific. The serological classification of $S$. milleri proposed here is totally independent of the Lancefield group antigens, A, C, F and G.

$S$. milleri possess Ottens type antigens $\mathrm{I}-\mathrm{V}$ in various combinations along with the Lancefield group antigens $\mathrm{C}, \mathrm{F}$ and $\mathrm{G}$ (Ottens and Winkier, 1962; Colman and Williams, 1972; Lütticken et al., 1978), suggesting the possibility that some of the typing antisera are specific to one or the other of the Ottens type antigens.

One of the most readily proved associations is that the anti- $f$ serum obtained by immunisation with $S$. MG ATCC 9895 contains antibodies specific to the Ottens type III antigen. The vaccine strain ATCC9895 has been shown to belong to Lancefield group F, Ottens type III, category F, III (Willers et al., 1964), but the usual preparations of the rabbit anti-ATCC9895 serum are reported to contain antitype III antibodies alone and not anti-group F antibodies (Willers et al., 1964). This may also be so for our own anti- $f$ serum. Any relationship of specific typing sera other than the anti- $f$ serum to the Ottens type antigens, I, II, IV and V is not known at present; clarification of the chemical properties of these type-specific antigens and their identities with the Ottens type antigens require further study.

\section{REFERENCES}

Admon D, Ephros M A, Gavish D, Raz R 1987 Infection with Streptococcus milleri. Journal of Infection 14: 55-60.

Aluyi H S, Drucker D B 1983 Trimethylsilyl-sugar profiles of Streptococcus milleri and Streptococcus mitis. Journal of Applied Bacteriology 54: 391-397.

Ball L C, Parker M T 1979 The cultural and biochemical characters of Streptococcus milleri strains isolated from human sources. Journal of Hygiene 82 : 63-78.

Bowden G H, Hardie J M, Slack G L 1975 Microbial variations in approximal dental plaque. Caries Research 9: 253-277.

Colman G, Williams R E O 1972 Taxonomy of some human viridans streptococci. In: Wannamaker $\mathbf{L}$ W, Matsen $\mathbf{J}$ M (eds) Streptococci and streptococcal diseases, Academic Press, London, p 281.

Coykendall A L, Wesbecher P M, Gustafson K B 1987 "Streptococcus milleri," Streptococcus constellatus, and Streptococcus intermedius are later synonyms of Streptococcus anginosus. International Journal of Systematic Bacteriology 37: 222-228.

Drucker D B, Green R M 1978 The relative cariogenicities of Streptococcus milleri and other viridans group streptococci in gnotobiotic hooded rats. Archives of Oral Biology 23: 183-187.

Drucker D B, Lee S M 1981 Fatty acid fingerprints of "Streptococcus milleri", Streptococcus mitis, and related species. International Journal of Systematic Bacteriology 31 : 219-225.
The crude anti-10708 serum did not react with the group $G$ antigen but cross-reacted with $R R$ extract of the untypable group $G$ strains. Furthermore, absorption of the crude antiserum with cells of the untypable group $\mathrm{G}$ strain $\mathrm{K} 214-2 \mathrm{~K}$ provided the specific anti- $b$ serum (table I). These results suggest that strain NCTC10708 carries two type antigens; one is serotype $b$-specific and the other is the same as that of strain $\mathrm{K} 214-2 \mathrm{~K}$. It should be noted that there is evidence for strain NCTC 10708 being a member of Lancefield group F. However, there have been discrepant descriptions with respect to the antigenic and physiological properties of this strain (Drucker and Green, 1978; Drucker and Lee, 1983). Reasons for these inconsistent findings are obscure but the strain may be prone to alter in antigenicity.

The proposed serotyping scheme for oral $S$. milleri is not yet established, but the typing sera could be useful not only to initiate classification of oral $S$. milleri but also to clarify the route of transmission of this clinically important streptococcus.

We thank Dr T. Koga (NIH, Tokyo) for helpful advice and discussion and also Miss Kayoko Yuge for typing the manuscript.

Drucker D B, Lee S M 1983 Possible heterogeneity of Streptococcus milleri determined by DNA mol\% (guanine plus cytosine) measurement and physiological characterization. Microbios 38: 151-157.

Edwardsson S, Mejàre B 1978 Streptococcus milleri (Guthof) and Streptococcus mutans in the mouths of infants before and after tooth eruption. Archives of Oral Biology 23: 811-814.

Kambal A M 1987 Isolation of Streptococcus milleri from clinical specimens. Journal of Infection 14: 217-223.

Labbe M, van der Auwera P, Glupczynski Y, Crockaert F, Yourassowsky E 1985 Fatty acid composition of Streptococcus milleri. European Journal of Clinical Microbiology 4: 391393.

Lütticken $\mathbf{R}$, Wendorff $\mathrm{U}$, Lütticken $\mathrm{D}$, Johnson $\mathrm{E} A$, Wannamaker L W 1978 Studies on streptococci resembling Streptococcus milleri and on an associated surface-protein antigen. Journal of Medical Microbiology 11 : 419-431.

Ottens H, Winkler K C 1962 Indifferent and haemolytic streptococci possessing group-antigen F. Journal of General Microbiology 28: 181-191.

Parker M T, Ball L C 1976 Streptococci and aerococci associated with systemic infection in man. Journal of Medical Microbiology 9: 275-302.

Poole P M, Wilson G 1979 Occurrence and cultural features of Streptococcus milleri in various body sites. Journal of Clinical Pathology 32: 764-768.

Rantz L A, Randall E 1955 Use of autoclaved extracts of hemolytic streptococci for serological grouping. Stanford Medical Bulletin 13: 290-291. 
Shlaes D M, Lerner P I, Wolinsky E, Gopalakrishna K V 1981 Infections due to Lancefield group $F$ and related streptococci (S. milleri, S. anginosus). Medicine 60: 197-207.

Van der Auwera P 1985 Clinical significance of Streptococcus milleri. European Journal of Clinical Microbiology 4: 386390.

Willers J M N, Ottens H, Michel M F 1964 Immunochemical relationship between Streptococcus MG, F III and Streptococcus salivarius. Journal of General Microbiology 37: 425431.

Yakushiji T, Katsuki M, Yoshimitsu A, Mizuno J, Inoue M Isolation and physiological characterization of Streptococcus milleri strains from human dental plaque. Microbios, in press. 